Культуры in vitro

\title{
ФИЗИОЛОГО-БИОХИМИЧЕСКИЕ ХАРАКТЕРИСТИКИ КЛЕТОЧНОЙ КУЛЬТУРЫ Saussurea orgaadayi V. Khan. and Krasnob. ПРИ ВОЗДЕЙСТВИИ МЕТА-ХЛОРБЕНЗГИДРИЛМОЧЕВИНЫ
}

\author{
И.Ф. ГОЛОВАЦКАЯ ${ }^{\otimes}$ А.Е. РЕЗНИЧЕНКО, Н.И. ЛАПТЕВ
}

\begin{abstract}
Мета-хлорбензгидрилмочевина (МХБМ) - индуктор монооксигеназной системы человека, ключевые ферменты которой относятся к суперсемейству цитохромов Р-450 (СУР). В настоящее время отсутствуют сведения о роли МХБМ в регуляции жизнедеятельности растений, однако показано участие СYР в превращении вторичных метаболитов, например флавоноидов (Фл), и большинства фитогормонов. Горькуша оргадаай (Saussurea orgaadayi V. Khan. and Krasnob.) малоизученный вид растений. Ее клеточная культура, в соответствии с нашими данными, 2-кратно увеличивает суммарное количество эндогенных Фл при переходе от экспоненциального роста в стационарную фазу. В настоящем исследовании впервые показаны статистически значимые $(\mathbf{p} \leq 0,05)$ различия в ответных ростовых реакциях каллусной культуры $S$. orgaadayi на действие МХБМ в разных концентрациях. Выявлено, что изменение ростового индекса по сырой и сухой массе обусловлено изменением объема и формы клеток, а также частоты встречаемости разных групा клеток. Впервые исследована динамика содержания флавоноидов, сопровождающая изменения роста культуры под влиянием МХБМ. Целью работы было определение роли мета-хлорбензгидрилмочевины в накоплении флавоноидов и изменчивости цитоморфологических характеристик (линейных размеров, объема и формы клеток, частоты встречаемости разных групп клеток, ростового индекса по сырой и сухой биомассе каллуса) каллусной культуры горькуши оргадаай. Каллусную культуру, полученную на основе семядольных эксплантов из стерильных проростков, многократно пассировали на модифицированной агаризованной питательной среде Мурасиге-Скуга (МС) с добавлением сахарозы, витаминов и регуляторов роста (0,8 мг/л 2,4-дихлорфеноксиуксусной кислоты и 0,5 мг/л 6-бензинаминопурина). Культуру выращивали в темноте при температуре $22-24{ }^{\circ} \mathrm{C}$ на среде МС с добавлением регуляторов роста и МХБМ (ООО «Синтегал», Россия) в концентрациях 0,01; 0,1; 1; 10; 100 мкМ. В контроле МХБМ не вносили. Продолжительность субкультивирования составила 30 сут, $2 / 3$ растительного материала использовали для определения сырой и сухой биомассы с последующим выделением флавоноидов, $1 / 3$ материала фиксировали в растворе Кларка в течение 2 сут. Для приготовления микропрепаратов каллусную культуру мацерировали в 3 н. растворе соляной кислоты при постоянном встряхивании до получения однородной суспензии клеток. Цитофотометрический анализ осуществляли с помощью световой микроскопии (видеокамера Moticam 2300, «Motic», Испания) с программным обеспечением. Определяли размеры 100 клеток для каждого варианта, оценивали их форму, вычисляли объем. Для расчета ростового индекса (РИ) определяли начальную (начало субкультивирования, Мо) и конечную сырую или сухую массу каллусов (на 30-е сут субкультивирования, Мзо) и выражали в процентах к контролю: РИ = (Мзо - Мо)/М0. Количественное определение содержания суммы Фл в каллусной культуре осуществляли на основе их комплексообразования с хлоридом алюминия и последующего измерения оптической плотности окрашенных растворов (спектрофотометр UV-1650, «Shimadzu Corp.», Япония). В результате исследований установлено дозозависимое действие МХБМ на рост клеток за счет их деления (при 0,1 мкМ) и растяжения (1-100 мкМ), которое сопровождалось увеличением РИсыр и РИсух каллусной культуры соответственно в $2,1-3,5$ и $1,5-2,9$ раза $($ р $<0,05)$. При концентрации 0,1 мкМ число мелких меристематических клеток увеличивалось на 16 \% относительно контроля. Одновременно усредненный объем клеток крупных размеров уменышался на $31 \%$ по сравнению с контролем, что указывало на торможение процессов растяжения клеток. С повышением концентрации МХБМ повышалась частота встречаемости клеток среднего (на 55 и $30 \%$ соответственно при 1 и 10 мкМ) и крупного (на 50 и $57 \%$ при 1 и 100 мкМ) размеров и увеличивался объем крупных (на $61 \%$ при 10 мкМ) и мелких (на $18 \%$ при 100 мкМ) клеток относительно контроля. МХБМ на 80-95\% (p < 0,05) уменышала суммарное количество эндогенных флавоноидов при активации ростовых процессов в клетках $S$. orgaadayi in vitro. Содержание суммы Фл максимально снижалось при 0,01 и 0,1 мкМ МХБМ и не имело значимых отличий от контроля при 100 мкМ МХБМ. Максимальное 3,5-кратное увеличение РИсыр, отмеченное на среде с 1 мкМ МХБМ, происходило на фоне снижения суммы Фл на $83 \%$. Препарат МХБМ можно использовать в растительной биотехнологии в качестве модулятора роста клеток каллусных культур за счет снижения содержания ингибирующих рост метаболитов. Для активации клеточного деления наиболее предпочтительна доза 0,1 мкм МХБМ, тогда как для изменения содержания Фл, 2-кратно увеличивающих биомассу культуры, следует применять 100 мкМ МХБМ.
\end{abstract}

Ключевые слова: Saussurea orgaadayi, клеточная культура, мета-хлорбензгидрилмочевина, морфогенез, флавоноиды. 
Растения, в отличие от животных и человека, характеризуются способностью синтезировать вторичные метаболиты. Среди последних выделяют многочисленную группу флавоноидов (Фл), в которой изучено более 6900 представителей (1). Эти метаболиты синтезируются из п-кумароилКоА последовательным воздействием различных ферментов, которые, как полагают, образуют слабо связанные с мембранами (например, с эндоплазматическим ретикулумом) упорядоченные макромолекулярные белковые комплексы - флавоноидные метаболоны $(1,2)$. При синтезе специфических Фл во время роста растений и в реакциях на стрессоры важную роль играет определенная локализация и продолжительность взаимодействий между специфическими белками $(1,3)$. Фл выполняют следующие физиологические функции: защиту от листогрызущих насекомых, патогенных микроорганизмов, ультрафиолетового излучения и света высокой интенсивности, привлечение насекомых-опылителей, ингибирование образования активных форм кислорода (АФК), участие в прорастании пыльцы, биологическую коммуникацию в ризосфере (нодуляция), повышение эффективности извлечения питательных веществ во время старения растения и его органов (3-6). Они способны к хелатированию металлов, что может служить механизмом in vivo для снижения токсичности (3). Кроме того, Фл выступают в качестве регуляторов развития, участвующих в изменении транспорта фитогормона индолил-3-уксусной кислоты (ИУК) и его метаболизма (7).

Так как Фл не синтезируются в организме животных и человека, эти соединения служат незаменимыми пищевыми компонентами. Природные Фл имеют низкую токсичность, поэтому их используют для профилактики и лечения различных патологий (8). Пищевые Фл с антиоксидантной активностью снижают частоту возникновения атеросклероза, сердечно-сосудистых заболеваний, диабета, тромбоза, воспаления при артрите, нейродегенеративных заболеваний (болезни Альцгеймера и Паркинсона), ожирения, гиперлипидемии и гипертонии (4). Кверцетин проявляет антипролиферативный эффект в отношении линий раковых клеток (9). Фл используют как сырье для промышленного производства фармакологических и косметических субстанций, в связи с чем возникает вопрос о контроле содержания Фл в растениях.

В качестве индукторов биосинтеза Фл рассматриваются не только негативные биотические и абиотические воздействия, но и эндогенные факторы, например гормональный баланс клеток, связанный с возрастом растения, его органов и клеточных культур $(5,10-12)$. Среди ферментов, участвующих в модификации Фл, выделяют цитохром-Р-450-зависимые монооксигеназы (СYР) - компоненты флавоноидных метаболонов $(1,2,13)$. Индуктором цитохром-Р-450-зависимой монооксигеназной системы человека может служить мета-хлорбензгидрилмочевина (МХБМ) (14), однако сведения о роли МХБМ в регуляции жизнедеятельности растений отсутствуют.

Изучение молекулярных механизмов действия веществ в растительном организме затруднено вследствие присутствия многочисленных структурных элементов на клеточном, тканевом и органном уровнях, а также большого числа происходящих в них метаболических процессов. В связи с этим наиболее удачным модельным объектом могут служить гетеротрофные клеточные культуры, упрощенные по строению и не проявляющие фотосинтетической активности.

В настоящем исследовании впервые показаны статистически зна- 
чимые $(\mathrm{p} \leq 0,05)$ различия в ответных ростовых реакциях каллусной культуры горькуши оргадаай (Saussurea orgaadayi V. Khan. and Krasnob.) на действие МХБМ в разных концентрациях. Выявлено, что изменение ростового индекса по сырой и сухой массе обусловлено изменением объема и формы клеток, а также частоты встречаемости разных групп клеток. Впервые исследована динамика содержания флавоноидов, сопровождающая изменения роста культуры под влиянием МХБМ.

Целью работы было определение роли мета-хлорбензгидрилмочевины в накоплении флавоноидов и изменчивости цитоморфологических характеристик (линейных размеров, объема и формы клеток, частоты встречаемости разных групп клеток, ростового индекса по сырой и сухой биомассе каллуса) каллусной культуры горькуши оргадаай.

Методика. Производное мочевины - мета-хлорбензгидрилмочевина (галодиф, Galodif, CAS: 124057-07-4) было синтезировано в Томском политехническом университете (15), правообладатели препарата ООО «Синтегал» и ООО «Наука, Техника, Медицина» (Россия). В работе использовали разведения матричного 100 мМ спиртового раствора МХБМ в концентрациях 0,$01 ; 0,1 ; 1 ; 10 ; 100$ мкМ.

Каллусную культуру многолетнего лекарственного растения горькуши оргадаай $S$. orgaadayi, полученную на основе семядольных эксплантов из стерильных проростков, многократно пассировали на модифицированной агаризованной питательной среде Мурасиге-Скуга (MC) с добавлением сахарозы, витаминов и регуляторов роста 0,8 мг/л 2,4-Д (2,4-дихлорфеноксиуксусная кислота) и 0,5 мг/л 6-БАП (6-бензинаминопурин) (16). Культуру выращивали в темноте при температуре $22-24^{\circ} \mathrm{C}$ на среде МС с добавлением регуляторов роста и МХБМ, в контроле МХБМ не вносили.

Продолжительность субкультивирования составила 30 сут, $2 / 3$ растительного материала использовали для определения сырой и сухой биомассы с последующим выделением флавоноидов, 1/3 материала фиксировали в растворе Кларка (96 \% этиловый спирт:ледяная уксусная кислота в соотношении 3:1) в течение 2 сут. Затем материал отмывали от фиксатора 96 $\%$ раствором этилового спирта (3 раза по 30 мин) до исчезновения запаха уксусной кислоты и хранили в $70 \%$ растворе этанола при $4{ }^{\circ} \mathrm{C}$ (17). Для приготовления микропрепаратов каллусную культуру мацерировали в 3 н. растворе соляной кислоты при постоянном встряхивании до получения однородной суспензии клеток.

Цитофотометрический анализ осуществляли с помощью световой микроскопии (видеокамера Moticam 2300, «Motic», Испания) с программным обеспечением. Для каждого варианта измеряли размеры (L - длина, D - ширина) 100 клеток. По соотношению L/D оценивали форму клеток: $1,0 \leq \mathrm{L} / \mathrm{D} \leq 1,14$ - округлые, $1,15 \leq \mathrm{L} / \mathrm{D} \leq 1,94-$ овальные, $\mathrm{L} / \mathrm{D} \geq 1,95$ вытянутые. Объем клеток вычисляли по формуле Ю.А. Цельникер (18) с учетом рассчитанного автором поправочного коэффициента $(\mathrm{k})$, который зависит от L/D. При L/D > 2,5 для определения объема клеток $\left(\mathrm{V}, \mathrm{MKM}^{3}\right)$ применяли формулу цилиндра $\mathrm{V}=\pi(\mathrm{D} / 2)^{2} \mathrm{Lk}$, при $\mathrm{L} / \mathrm{D} \leq 2,5-$ формулу эллипсоида вращения $\mathrm{V}=4 / 3 \pi \mathrm{L} / 2(\mathrm{D} / 2)^{2}$. Для расчета ростового индекса (РИ) определяли начальную (начало субкультивирования, М0) и конечную сырую или сухую массу каллусов (на 30-е сут субкультивирования, М30) и выражали в процентах к контролю: РИ $=\left(\mathrm{M}_{30}-\mathrm{M}_{0}\right) / \mathrm{M}_{0}$.

Количественное определение содержания суммы Фл в каллусной культуре $S$. orgaadayi осуществляли на основе их комплексообразования 
с хлоридом алюминия и последующего измерения оптической плотности окрашенных растворов (спектрофотометр UV-1650, «Shimadzu Corp.», Япония) (19). Навеску сухого растительного сырья (1 г) трижды (по 60 мин) экстрагировали 70 \% этиловым спиртом на кипящей водяной бане, экстракты объединяли. Аликвоту объединенного растительного экстракта выдерживали в течение 40 мин в присутствии хлористого алюминия и уксусной кислоты. Раствор сравнения, не содержащий хлористого алюминия, готовили для каждой пробы отдельно.

После взаимодействия веществ определяли оптическую плотность опытного раствора и стандартного раствора рутина при $\lambda=415$ нм. Вычисляли суммарное содержание Фл в пересчете на рутин и абсолютно сухое сырье $($ Хлл):

$$
\text { ХФл }=\mathrm{OD}_{\mathrm{x}} \cdot \mathrm{K}_{\mathrm{x}} \cdot \mathrm{m}_{\mathrm{pyт}} \cdot 100 \cdot 100 \cdot \mathrm{OD}_{\mathrm{pyт}^{-1}} \cdot \mathrm{K}_{\mathrm{pyт}^{-1}} \cdot \mathrm{m}_{\mathrm{x}}^{-1} \cdot(100-\mathrm{W})^{-1} \text {, }
$$

где $\mathrm{OD}_{\mathrm{x}}$ - оптическая плотность исследуемого раствора; ODрут - оптическая плотность раствора рутина; $\mathrm{m}_{\mathrm{x}}$ - сырья масса, г; трут - масса рутина, г; $\mathrm{K}_{\mathrm{x}}$ - коэффициент разбавления исследуемого раствора (1250); Крут - коэффициент разбавления раствора рутина (2500); W - потеря в массе при высушивании сырья, \%.

При статистической обработке результатов в программе IBM SPSS Statistics («IBM Corporation», США) для Windows использовали параметрический $t$-критерий Стьюдента и непараметрический U-критерий МаннаУитни для парного сравнения параметров групп. На рисунках представлены средние арифметические значения $(M)$ для ростовых $(n=100)$ и биохимических $(n=5)$ параметров с двухсторонними доверительными интервалами ( $M \pm 1,96 \mathrm{SEM})$. Различия между значениями, отмеченные разными буквами, статистически значимы при р $<0,05$.

Результаты. В проведенных экспериментах изучали зависимость морфогенеза и аккумуляции Фл у медленнорастущей каллусной культуры $S$. orgaadayi, полученной на основе семядолей, от концентрации МХБМ в питательной среде (рис. 1). На выбор культуры повлияли наши предварительные исследования (20), показавшие 3-кратное превышение содержания Фл $(0,026 \pm 0,006 \%$ к сухой массе) на 25-е сут в медленнорастущей культуре по сравнению с активно растущей, полученной на основе гипокотилей проростков $S$. orgaadayi.

A

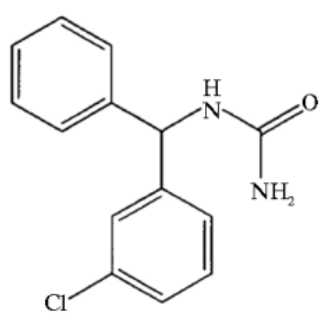

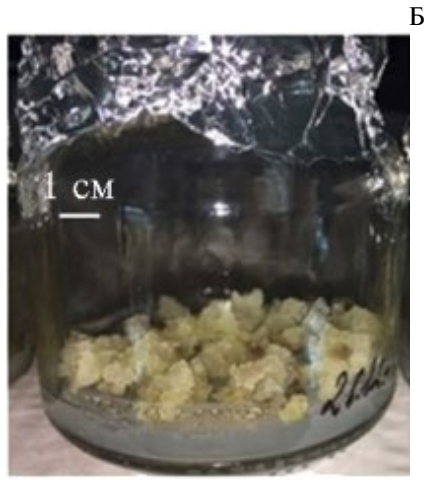

Рис. 1. Формула мета-хлорбензгидрилмочевины (А) и каллусная культура клеток, полученная на основе семядольных эксплантов проростков горькуши оргадаай (Saussurea orgaadayi V. Khan. and Krasnob.) (Б).

При выборе времени субкультивирования каллуса руководствовались данными о приросте сырой массы у контрольной культуры. Рост каллус- 
ной культуры описывался S-образной кривой с несколькими фазами ростового цикла: лаг-фазой, или периодом медленного роста, в течение первых 10 сут, логарифмической фазой с длительностью 15 сут, 5-суточной фазой замедления и, начиная с 30-х сут, стационарной фазой (данные не приведены). На 25-е сут субкультивирования РИсыр культуры в контроле

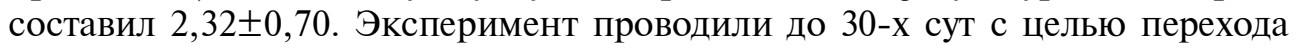
культуры в стационарную фазу роста и увеличения выхода вторичных метаболитов Фл, что согласуется с данными других авторов (12).

Добавление МХБМ в питательную среду в концентрациях 0,1100 мкМ увеличило прирост биомассы каллусной культуры. РИсыр и РИсух увеличивались соответственно в 2,1-3,5 и 1,5-2,9 раза (p $<0,05)$ относительно контроля (рис. 2). Действие 0,01 мкМ МХБМ не изменило РИсыр, но снизило РИсух на $20 \%$ ( $<<0,05)$. Наибольшие значения РИсыр и РИсух были отмечены при использовании 1 мкМ МХБМ. При этом в опыте каллусная культура отличалась от контрольной более светлой и рыхлой консистенцией.

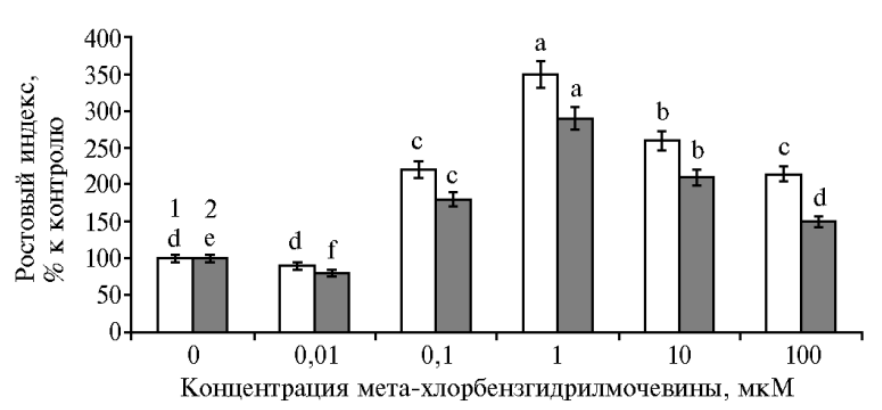

Рис. 2. Относительный прирост сырой (1) и сухой (2) биомассы каллусной культуры горькуши оргадаай (Saussurea orgaadayi V. Khan. and Krasnob.) в зависимости от концентрации мета-хлорбензгидрилмочевины. Различия между значениями каждого показателя, отмеченные разными буквами, статистически значимы при $\mathrm{p}<0,05(M \pm 1,96 \mathrm{SEM})$.

Цитологический анализ выявил морфологическую гетерогенность популяции клеток культуры $S$. orgaadayi (рис. 3, 4). Мы выделили группы клеток, которые различались по форме (округлые, овальные и вытянутые) и размеру (мелкие, средние и крупные). Мелкие клетки (9,0-35,7 тыс. мкм³) мы рассматривали как меристематические делящиеся, средние (35,75-75,94 тыс. мкм³) - как растущие, крупные (76,0323,2 тыс. мкм $\left.{ }^{3}\right)$ - как завершившие рост.

Контрольная каллусная культура на 30-е сут характеризовалась большей частотой встречаемости мелких клеток, чем средних и крупных соответственно в 1,6 и 3,4 раза (рис. 3, Б). Средний объем мелких клеток составлял $20,2 \pm 2,3$ тыс. мкм ${ }^{3}$, тогда как средних и крупных - соответственно 51,5 $\pm 1,4$ и $112,1 \pm 2,6$ тыс. мКм ${ }^{3}$ (рис. 3, А).

Результатом действия МХБМ на каллусную культуру было изменение роста клеток. При концентрации 0,1 мкМ количество мелких меристематических клеток увеличивалось на 16 \% относительно контроля, что могло свидетельствовать об усилении клеточного деления (см. рис. 3, Б). Одновременно усредненный объем клеток крупных размеров уменьшался на $31 \%$ по сравнению с контролем (см. рис. 3, А), что указывало на торможение процессов растяжения клеток. С повышением концентрации МХБМ увеличивалась частота встречаемости клеток среднего (на 55 и $30 \%$ соответственно при 1 и 10 мкМ) и крупного (на 50 и $57 \%$, р < 0,05 при 1 и 100 мкМ) размеров (см. рис. 3, Б) и увеличивался объем крупных (на $61 \%$, р < 0,05 при 10 мкМ) и мелких (на $18 \%, \mathrm{p}<0,05$ при 100 мкМ) клеток относительно контроля. На этом фоне уменьшалось количество мелких клеток (на 49, 20 и $30 \%$, $\mathrm{p}<0,05$ соответственно при 1,10 и 100 мкМ) и их объем (на 22 и $17 \%, \mathrm{p}<$ 0,05 при 1 и 10 мкМ) (см. рис. 3). 

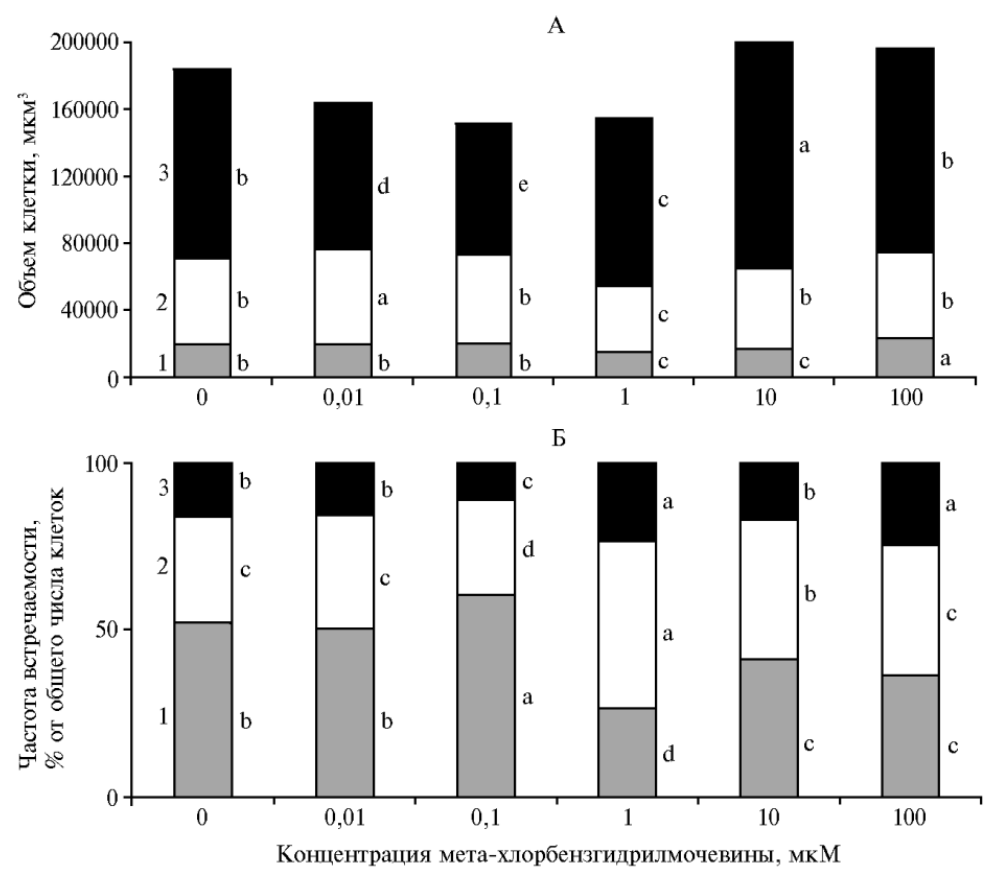

Рис. 3. Объем клетки (А) и частота встречаемости клеток разного размера (Б) в каллусной культуре горькуши оргадаай (Saussurea orgaadayi V. Khan. and Krasnob.) в зависимости от конщентрации мета-хлорбензгидрилмочевины: 1 - мелкие, 2 - средние, 3 - крупные клетки. Различия между значениями каждого показателя, отмеченные разными буквами, статистически значимы при $\mathrm{p}<0,05$.
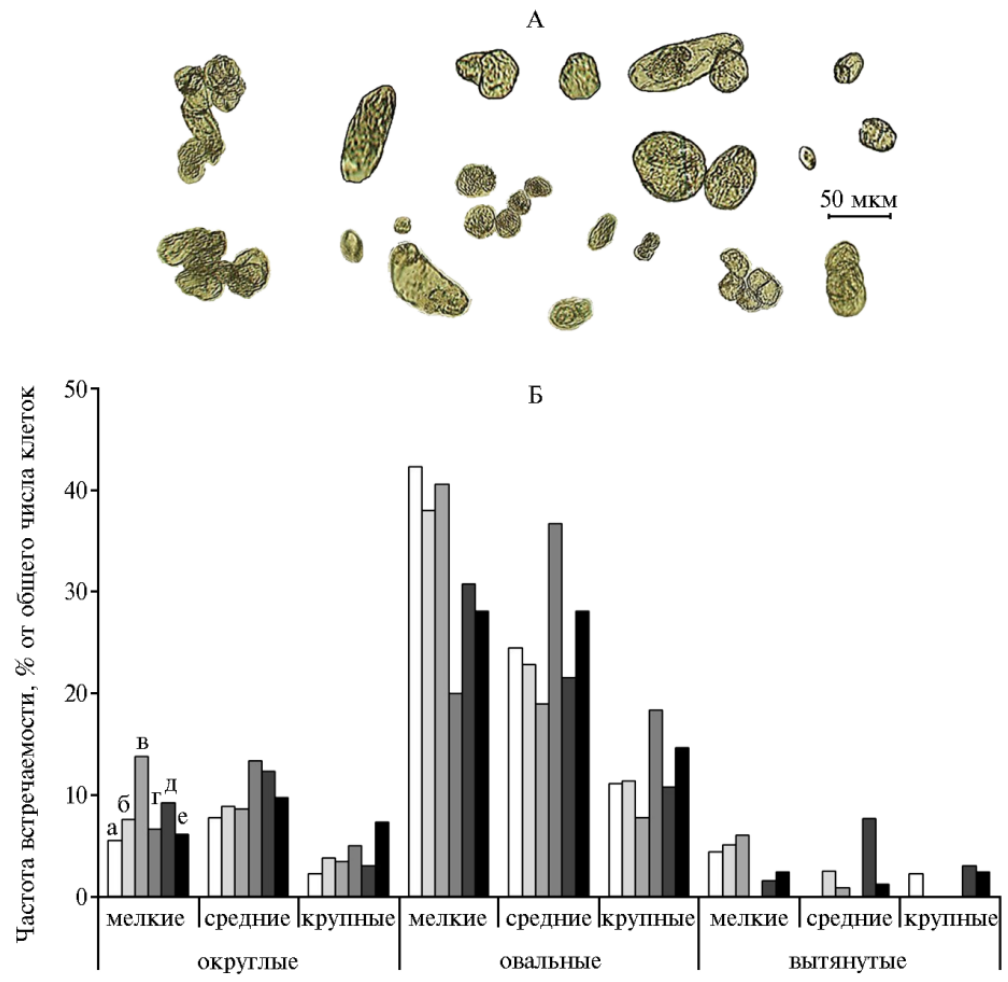

Рис. 4. Форма (А) и частота встречаемости (Б) клеток разной формы и размеров в каллусной культуре горькуши оргадаай (Saussurea orgaadayi V. Khan. and Krasnob.) в зависимости от концентрации мета-хлорбензгидрилмочевины: $\mathrm{a}-0$ (контроль); б-0,01 мкМ; в - 0,1 мкМ; г1 мкМ; д - 10 мкМ; е - 100 мкМ. 
Под действием МХБМ увеличивалась доля округлых клеток всех размеров (рис. 4, Б). Наибольшие изменения наблюдали в частоте встречаемости мелких клеток (повышение в 2,5 раза, $\mathrm{p}<0,05)$ при концентрации 0,1 мкМ МХБМ, средних и крупных клеток (рост соответственно в $1,7$ и 2,3 раза, $\mathrm{p}<0,05)$ - при 1 мкМ МХБМ. Наибольшая (увеличенная в $3,3$ раза, $\mathrm{p}<0,05)$ частота встречаемости крупных клеток округлой формы была отмечена при 100 мкМ МХБМ.

Изменение ростовых процессов в культуре могло свидетельствовать об изменении количества эндогенных веществ, осуществляющих регуляцию роста. Среди последних называют Фл, модулирующие гомеостаз растительных гормонов ауксинов (7). Мы установили, что суммарное содержание Фл у контрольной культуры в процессе субкультивирования на стационарной стадии (30-е сут) составило $0,049 \pm 0,008 \%$ к сухой массе, что на $50 \%(\mathrm{p}<0,05)$ больше, чем на 25 -е сут в точке перегиба логарифмического участка кривой роста. Эти данные свидетельствуют о замедлении роста на фоне повышения содержания эндогенных Фл.

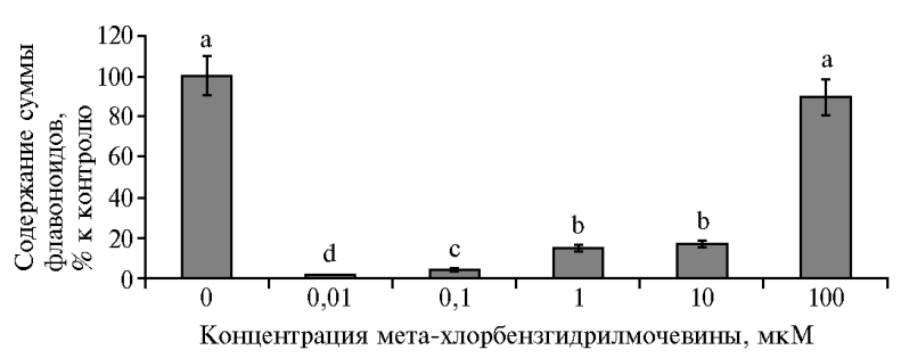

Рис. 5. Содержание суммы флавоноидов в каллусной культуре горькуши оргадаай (Saussurea orgaadayi V. Khan. and Krasnob.) в зависимости от концентрации мета-хлорбензгидрилмочевины. Различия между значениями, отмеченные разными буквами, статистически значимы при р $<0,05$ ( $M \pm 1,96 \mathrm{SEM})$.

При действии МХБМ происходило изменение суммарного содержания Фл по сравнению с контролем (рис. 5). Впервые показано, что уменьшение (на 80-95\%) суммарного количества эндогенных Фл под действием МХБМ сопровождалось активацией ростовых процессов в растительных клетках S. orgaadayi in vitro. Содержание суммы Фл максимально снижалось при низких концентрациях МХБМ и сохранялось на уровне контроля при 100 мкМ МХБМ. Максимальный (в 3,5 раза) прирост биомассы, отмеченный при 1 мкМ МХБМ, происходил на фоне снижения суммы Фл на $83 \%$.

Таким образом, в нашем исследовании было показано влияние МХБМ на рост каллусной культуры $S$. orgaadayi, что, вероятно, обусловлено его действием на растяжение и деление клеток. Дозозависимые изменения в накоплении биомассы культуры (см. рис. 2) сопровождались изменением частоты встречаемости клеток разных размеров и формы (см. рис. 3, 4). Действие МХБМ в самой низкой концентрации (0,01 мкМ) снижало РИ сух, что могло определяться снижением объема крупных клеток на $23 \%$ при равном контролю соотношении ранжированных по размеру групп клеток. Наибольшие РИсыр и РИсух культуры, отмеченные при действии 1 мкМ МХБМ, сопровождались повышенной частотой встречаемости средних и крупных клеток и снижением доли мелких клеток (см. рис. 3, Б). Концентрация 0,1 мкМ МХБМ оказывала меньший эффект, чем 1 мкМ МХБМ, что проявлялось в повышении частоты встречаемости мелких клеток и, соответственно, в снижении доли средних и крупных.

Наиболее активными концентрациями МХБМ в регуляции роста каллусной культуры горькуши оргадаай были 0,1-10 мкМ, под действием которых увеличивалось число меристематических округлых мелких клеток. 
Ускорение роста сопровождалось изменением вторичного метаболизма, что выразилось в снижении суммарного количества Фл на 80-95\% (p < 0,05) относительно контроля (см. рис. 5). Действие МХБМ в высокой концентрации 100 мкМ достоверно увеличивало прирост биомассы культуры, существенно не меняя содержание Фл. Дозозависимая динамика роста и содержания Фл под действием МХБМ, вероятно, может свидетельствовать об изменении функционирования ферментов, участвующих в метаболизме Фл. На модификацию Фл в клеточной культуре указывают данные других авторов (21), изучавших комплексное воздействие экзогенных факторов (кадмия и глифосата) на суммарное содержание фенольных соединений, которое возрастало на фоне снижения количества фенилпропаноидов и флавоноидов.

На рост каллусной культуры могли оказывать действие Фл с разными свойствами. Наряду с антиоксидантными свойствами катехинов и кверцетина некоторые Фл в высоких дозах могут проявлять прооксидантную активность и повреждать клетки (8).

Показано влияние Фл на регуляцию клеточного цикла (22). В качестве возможных механизмов называют непосредственное взаимодействие Фл (например, кверцетина) с протеинкиназами Raf и MEK, обусловливающими проведение митотических сигналов, или их связывание с рецептором $\mathrm{AhR}$ и образование комплекса с ARNT, стимулирующего транскрипцию ингибитора клеточного цикла CDKNB1 $(22,23)$.

Кроме того, возможно и опосредованное действие Фл на рост, связанное с изменением транспорта ауксинов и их метаболизма. Известно, что пространственно-временное распределение ауксинов, обусловленное механизмами полярного транспорта, играет решающую роль в их физиологических эффектах (24). На примере мутантов $t t 4$ показано, что дефицит Фл усиливает поток ИУК (25). Считается, что флавонолы непосредственно модулируют транспорт ИУК - процесс, который снижается в сверхаккумулирующем кемпферол мутанте $t t 7$, дефектном по F39H (25). Негликозилированные кемпферол и кверцетин конкурируют с ингибитором транспорта ауксина 1-N-нафтилфталаминовой кислотой за высокоаффинный сайт связывания комплекса, содержащего белки PGP1, PGP2 и MDR1/PGP19, которые принадлежат к АТФ-связывающим кассетным переносчикам. В то же время Фл выступают в качестве регуляторов ИУК-оксидазы, участвующей в деградации ИУК: Фл с о-гидроксилами в ядре В (кверцетин, мирицетин, лютеолин) ингибируют активность фермента, тогда как Фл с п-гидроксилами (апигенин, нарингенин, нарингин) стимулируют его (26). В итоге первая группа Фл стимулирует рост, а вторая - ингибирует его.

В то же время неотъемлемым этапом нормального роста и развития растений считается окисление Фл, которое связано с деятельностью растительных пероксидаз или других ферментов $(27,28)$. В результате окисления Фл способны проявлять прооксидантное действие, которое выражается в повреждении биологических структур и общем снижении жизнеспособности клеток организма (28).

Исследуемый нами препарат МХБМ может регулировать активность гемсодержащих ферментов семейства цитохромов Р-450 (СҮР), принадлежащих к группе монооксигеназ у человека. Ферменты этой группы обнаружены во всех царствах и катализируют разнообразные химические реакции $(13,25)$. Изменения роста клеток культуры $S$. orgaadayi под действием МХБМ, сопровождавшиеся изменением содержания Фл, вероятно, также можно объяснить регуляцией функционирования СYР, участвующих в 
метаболизме Фл (2). Показано, что $C Y P 82 D$ кодирует флавон-6-гидроксилазу и 7-деметилазу и отвечает за биосинтез Фл в сладком базилике, тогда как СYР75 регулирует экспрессию флавоноид-3'-гидроксилазы и флавоноид-3',5'-гидроксилазы, которые участвуют в синтезе большинства антоцианов, в красном винограде (13). CYP93G1, ближайший гомолог CYP93G2 в рисе, - это флавон-синтаза II (FNSII), которая катализирует прямое превращение флаванонов в флавоны (30).

Другими эндогенными факторами роста клеток культуры горькуши могли выступать фитогормоны, в регуляции метаболизма которых также участвуют CYP. Например, CYP79B2/B3 ответствен за превращение L-триптофана (L-Trp) в индол-3-ацетальдоксим в альтернативном L-Trp-зависимом пути биосинтеза ауксинов (13), цитокинин-гидроксилазы CYP735A1 и CYP735A2 катализируют биосинтез транс-зеатинов, а СYP72C1 инактивирует брассиностероиды у Arabidopsis thaliana $(13,25)$.

Возможны и мембранные механизмы действия МХБМ на растительные клетки по аналогии с клетками человека. Такие механизмы могут быть связаны с блокадой быстрых натриевых каналов нейронов, ограничивающей распространение электрического потенциала. В результате МХБМ за счет регулирования водно-электролитного баланса стабилизирует концентрационный градиент ионов, а также препятствует изменению мембранной проницаемости и трансмембранного потенциала клетки. Наряду с этим МХБМ усиливает процессы микросомального окисления, проявляя детоксицирующее действие в клетках.

В соответствии с полученными нами данными, высокое содержание Фл на 30-е сут субкультивирования обусловливало завершение активного роста клеток каллуса у $S$. orgaadayi в контрольном варианте, что согласуется с данными по увеличению аккумуляции Фл на стационарной стадии клеточной культуры $(11,12)$ и в завершивших рост листьях растений Lactuca sativa L. (5). Также показано $(12,29)$, что в процессе длительного культивирования клеток суспензионной культуры повышается окислительный статус (накопление АФК) и происходит активация антиоксидантных ферментов и вторичных метаболитов. В связи с этим следует ожидать, что действие МХБМ увеличивает биомассу культуры, вероятно, за счет снижения количества Фл и, соответственно, увеличения продолжительности ростовой активности клеток.

На основе наших результатов и данных других авторов $(2,12,25,28$ 30), полученных при исследовании растений и их клеточных культур, можно предполагать влияние МХБМ на активность ферментов, регулирующих содержание Фл и фитогормонов, а также ферментативных антиоксидантов.

Итак, используемая в эксперименте медленнорастущая каллусная культура горькуши оргаадай, полученная из семядольного экспланта, продуцировала флавоноиды. Введение экзогенной мета-хлорбензгидрилмочевины (МХБМ) в питательную среду в концентрации от 0,01 до 10 мкМ обусловливало снижение содержания вторичных метаболитов в каллусной культуре. Уменьшение суммарного содержания флавоноидов приводило к активации ростовых процессов. Происходило накопление биомассы каллуса и повышение ростового индекса культуры с максимумом при 1 мкМ МХБМ. Дальнейшее увеличение концентрации МХБМ снижало темпы прироста биомассы. Рост биомассы культуры сопровождался изменением частоты встречаемости разных типов клеток и размеров. При действии 0,1 мкм МХБМ увеличивалось число мелких меристематических клеток, а начиная с 1 мкМ МХБМ, возрастала частота встречаемости округлых и овальных 
клеток среднего и крупного размера при уменышении встречаемости мелких клеток. При этом клетки достигали наибольших размеров при концентрации 10 мкM, а максимальное число крупных клеток отмечали при 100 мкМ МХБМ. Такая динамика указывала на увеличение скорости деления клеток при низких концентрациях и растяжения клеток - при средних и высоких концентрациях МХБМ. Полученные данные свидетельствуют о дозозависимом действии МХБМ на рост клеток через изменение содержания флавоноидов.

Авторы выражают благодарность сотрудникам ООО «Синтегал» (г. Томск) за предоставление раствора мета-хлорбензгидрилмочевины и сотруднику кафедры физиологии растений, биотехнологии и биоинформатики ТГУ Ю.В. Медведевой за поддержание коллекции клеточной культуры растений Saussurea orgaadayi.

\section{ЛИТЕРАТУРА}

1. Nakayama T., Takahashi S., Waki T. Formation of flavonoid metabolons: functional significance of protein-protein interactions and impact on flavonoid chemodiversity. Frontiers in Plant Science, 2019, 10: 821 (doi: 10.3389/fpls.2019.00821).

2. Ayabe S., Akashi T. Cytochrome P450s in flavonoid metabolism. Phytochemistry Reviews, 2006, 5: 271-282 (doi: 10.1007/s11101-006-9007-3).

3. Falcone-Ferreyra M.L., Rius S.P., Casati P. Flavonoids: biosynthesis, biological functions, and biotechnological applications. Frontiers in Plant Science, 2012, 3: 222 (doi: 10.3389/fpls.2012.00222).

4. Mouradov A., Spangenberg G. Flavonoids: a metabolic network mediating plants adaptation to their real estate. Frontiers in Plant Science, 2014, 5: 620 (doi: 10.3389/fpls.2014.00620).

5. Головацкая И.Ф., Бойко Е.В., Видершпан А.Н., Лаптев Н.И. Возрастные морфофизиологические и биохимические изменения у растений Lactuca sativa L. под влиянием селена и света разной интенсивности. Сельскохозяйственная биология, 2018, 53(5): 1025-1036 (doi: 10.15389/agrobiology.2018.5.1025rus).

6. Kumar V., Suman U., Rubal, Yadav S.K. Flavonoid secondary metabolite: biosynthesis and role in growth and development in plants. In: Recent trends and techniques in plant metabolic engineering /S. Yadav, V. Kumar, S. Singh (eds.). Springer, Singapore, 2018: 19-45 (doi: 10.1007/978-98113-2251-8_2).

7. Kuhn B.M., Errafi S., Bucher R., Dobrev P., Geisler M., Bigler L., Zažímalová E., Ringli C. 7rhamnosylated flavonols modulate homeostasis of the plant hormone auxin and affect plant development. The Journal of Biological Chemistry, 2016, 291(10): 5385-5395 (doi: 10.1074/jbc.M115.701565).

8. Белицкий Г.А., Кирсанов К.И., Лесовая Е.А., Якубовская М.Г. Механизмы антиканцерогенного действия флавоноидов. Успехи молекулярной онкологии, 2014, 1(1): 56-68.

9. Ionkova I. Optimization of flavonoid production in cell cultures of Astragalus missouriensis Nutt. (Fabaceae). Pharmacognosy Magazine, 2009, 5(18): 92-97.

10. Indu S., Vijaya L., Meeta B., Jossy V., Naresh C. Production of flavonoids in callus culture of Anthocephalus indicus A. Rich. Asian Journal of Plant Sciences, 2013, 12(1): 40-45 (doi: 10.3923/ajps.2013.40.45).

11. Березина Е.В., Брилкина А.А., Щурова А.В., Веселов А.П. Накопление биомассы и фенольных соединений каллусами Oxycoccus palustris Pers. и O. macrocarpus (Ait.) Pers. в присутствии разных цитокининов. Физиология растений, 2019, 66(1): 35-45 (doi: 10.1134/S0015330318050032).

12. Wang J., Qian J., Yao L., Lu Y. Enhanced production of flavonoids by methyl jasmonate elicitation in cell suspension culture of Hypericum perforatum. Bioresources and Bioprocessing, 2015, 2: 5 (doi: 10.1186/s40643-014-0033-5).

13. Xu J., Wang X., Guo W. The cytochrome P450 superfamily: key players in plant development and defense. Journal of Integrative Agriculture, 2015, 14(9): 1673-1686 (doi: 10.1016/s20953119(14)60980-1).

14. Новожеева Т.П., Чурсина И.Э., Новожеева А.В., Саратиков А.С. Влияние бензонала, галонала и галодифа на систему микросомального окисления гепатоцитов в онтогенезе. $X u$ мико-фармацевтический журнал, 2004, 38(2): 7-9.

15. Штрыкова В.В., Куксёнок В.Ю., Филимонов В.Д., Галанов А.И. Способ получения метахлорбензгидрилмочевины (галодифа) с использованием магнитных наночастиц, модифицированных сульфогруппами. А.с. 2569684 (РФ). МПК СО7С 275/24, СО7С 273/18. ФГАО УВО ТПУ (РФ). № 2014154126/06. Заявл. 29.12.2014. Опубл. 27.11.2015. Бюл. № 33.

16. Карначук Р.А., Лихачева А.В. Питательная среда для культивирования клеточной культуры 
Saussurea orgaadayi V. Khan. Et Krasnov. A.c. 2428472 (РФ). МПK C12N 005/02, C12N 005/04. ГОУ ВПО ТГУ (РФ). № 2010118803. Заявл. 05.11.2010. Опубл. 09.10. 2011. Бюл. № 25.

17. Барыкина Р.П., Веселова Т.Д., Девятов А.Г, Джалилова Х.Х., Ильина Г.М., Чубатова Н.В. Основы микротехнических исследований в ботанике. Справочное руководство. М., 2000.

18. Цельникер Ю.Л. Физиологические основы теневыносливости древесных растений. М., 1978.

19. Государственная фармакопея СССР: Вып. 2. Общие методы анализа. Лекарственное растительное сырье. 11-е изд. М., 1989.

20. Головацкая И.Ф., Бойко Е.В., Резниченко А.Е., Плюснин И.Н. Мелатонин и селен регулируют рост и окислительный статус клеточных культур Saussurea orgaadayi in vitro, полученных от разных эксплантов. Физиология растений, 2020, 67(6): 625-635 (doi: $10.31857 / \mathrm{S} 001533032005005 \mathrm{X})$.

21. Гончарук Е.А., Николаева Т.Н., Назаренко Л.В., Калашникова Е.А., Загоскина Н.В. Ответная реакция культивируемых in vitro клеток Linum grandiflorum Desf. на действие кадмия и глифосата. Сельскохозяйственная биология, 2018, 53(5): 938-946 (doi: 10.15389/agrobiology.2018.5.938rus).

22. Galati G., Sabzevari O., Wilson J.X., O'Brien P.J. Prooxidant activity and cellular effects of the phenoxyl radicals of dietary flavonoids and other polyphenolics. Toxicology, 2002, 177(1): 91-104 (doi: 10.1016/s0300-483x(02)00198-1).

23. Brunetti C., Di Ferdinando M., Fini A., Pollastri S., Tattini M. Flavonoids as antioxidants and developmental regulators: relative significance in plants and humans. International Journal of Molecular Sciences, 2013, 14(2): 3540-3555 (doi: 10.3390/ijms 14023540).

24. Pař́zková B., Pernisová M., Novák O. What has been seen cannot be unseen-detecting auxin in vivo. International Journal of Molecular Sciences, 2017, 18(12): 2736 (doi: 10.3390/ijms18122736).

25. Sotelo-Silveira M., Cucinotta M., Chauvin A.-L., Chávez Montes R.A., Colombo L., MarschMartínez N., de Folter S. Cytochrome P450 CYP78A9 is involved in Arabidopsis reproductive development. Plant Physiology, 2013, 162(2): 779-799 (doi: 10.1104/pp.113.218214).

26. Макаренко О.А., Левицкий А.П. Физиологические функции флавоноидов в растениях. Физиология и биохимия культурных растений, 2013, 45(2): 108-112.

27. Pourcel L., Routaboul J., Cheynier V., Lepiniec L., Debeaujon I. Flavonoid oxidation in plants: from biochemical properties to physiological functions. Trends in Plant Science, 2007, 12(1): 2936 (doi: 10.1016/j.tplants.2006.11.006).

28. Червяковский Е.М., Курченко В.П., Костюк В.А. Роль флавоноидов в биологических реакциях с переносом электронов. Труды Белорусского Государственного Университета. Серия: Физиологические, биохимические и молекулярные основы функционирования биосистем, 2009, 1: 9-26.

29. Kim Y.-H., Kim Y., Cho E., Kwak S., Kwon S., Bae J., Lee B., Meen B., Huh G.-H. Alterations in intracellular and extracellular activities of antioxidant enzymes during suspension culture of sweetpotato. Phytochemistry, 2004, 65(17): 2471-2476 (doi: 10.1016/j.phytochem.2004.08.001).

30. Lam P.Y., Zhu F.-Y., Chan W.L., Liu H., Lo C. Cytochrome P450 93G1 is a flavone synthase II that channels flavanones to the biosynthesis of tricin o-linked conjugates in rice. Physiology, 2014, 165(3): 1315-1327 (doi: 10.1104/pp.114.239723).

\title{
ФГАОУ ВО Наииональный исследовательский \\ Томский государственный университет, \\ Поступила в редакцию
}

Биологический институт,

634050 Россия, г. Томск, пр. Ленина, 36,

e-mail: golovatskaya.irina@mail.ru $₫$, chg.angel@mail.ru,experteco@mail.ru

Sel'skokhozyaistvennaya biologiya [Agricultural Biology], 2021, V. 56, № 3, pp. 602-613

\section{INFLUENCE OF META-CHLORO-BENZHYDRYL UREA ON PHYSIOLOGICAL AND BIOCHEMICAL CHARACTERISTICS OF Saussurea orgaadayi V. Khan. and Krasnob. CELL CULTURE}

\author{
I.F. Golovatskaya ${ }^{凶}$, A.E. Reznichenko, N.I. Laptev
}

National Research Tomsk State University, 36, pr. Lenina, Tomsk, 634050 Russia, e-mail golovatskaya.irina@mail.ru (corresponding author $\varangle$ ), chg.angel@mail.ru, experteco@mail.ru

ORCID:

Golovatskaya I.F. orcid.org/0000-0002-1919-1893

Reznichenko A.E. orcid.org/0000-0002-0314-6510

The authors declare no conflict of interests

Acknowledgements:

The authors express their gratitude to the staff of LLC «Sintegal» (Tomsk) for providing with meta-chloro-benzhydryl urea preparation and to the employee of the Department of Plant Physiology, Biotechnology and Bioinformatics of TSU Yu.V. Medvedeva for maintaining the collection of Saussurea orgaadayi plant cell culture.

Received December 6, 2020 doi: 10.15389/agrobiology.2021.3.602eng 
Meta-chloro-benzhydryl urea (m-CBU) is an inducer of the human monooxygenase system, its key enzymes belong to the cytochrome P-450 superfamily (CYP). Currently, there is no information about the role of $\mathrm{m}-\mathrm{CBU}$ in the plant vital activity regulation; however, the participation of CYP in the metabolism of secondary metabolites, for example, flavonoids ( $\mathrm{Fl})$, and most phytohormones have been shown. Saussurea orgaadayi V. Khan. and Krasnob. is a poorly studied plant species. Its cell culture, in accordance with our data, doubles the total amount of endogenous Fl during the transition from exponential growth to the stationary phase. The present study, for the first time shows statistically significant $(\mathrm{p}<0.05)$ differences in the growth responses of the callus culture of the $S$. orgaadayi to $\mathrm{m}-\mathrm{CBU}$ in different concentrations. It was revealed that the change in the growth index in terms of fresh and dry weight is related to a change in the volume and shape of cells, as well as the occurrence frequency of different groups of cells. Here, for the first time, the dynamics of the content of Fl, accompanying changes in the growth of culture under the influence of $m-C B U$ was assessed. The aim of this work was to determine the role of meta-chloro-benzhydryl urea in the accumulation of flavonoids and the variability of cytomorphological characteristics of $S$. orgaadayi callus culture (cell linear dimensions, volume and shape, the frequency of cells of different sizes, growth index for the fresh and dry biomass). A callus culture derived from cotyledon explants of sterile seedling was repeatedly passaged on a modified Murashige-Skoog (MS) agar nutrient medium supplemented with sucrose, vitamins and growth regulators $0.8 \mathrm{mg} / 12,4-\mathrm{D}$ and $0.5 \mathrm{mg} / 1$ 6-BAP. The culture was grown in the dark at a temperature of $22-24{ }^{\circ} \mathrm{C}$ in $\mathrm{MS}$ medium added with growth regulators and $0.01,0.1,1,10$, or $100 \mu \mathrm{M}$ m-CBU (Sintegal, LLC, Russia). In the control, m-CBU was not added. After 30 days of subculture, $2 / 3$ of the material was used to determine the wet and dry biomass followed by the isolation of flavonoids, and $1 / 3$ of the material was fixed in Clark's solution for 2 days. To prepare micropreparations, the cell culture was macerated in a $3 \mathrm{~N}$ hydrochloric acid solution with constant shaking until a homogeneous cell suspension was obtained. Cytophotometric analysis was performed using light microscopy (video camera Moticam 2300, Motic, Spain) with software. The sizes of 100 cells were measured for each variant, their shape was estimated, and the volume was calculated. To calculate the growth index (GI), the initial (beginning of subcultivation, $\mathrm{M} 0$ ) and the final fresh or dry weight of calli (on day 30 of subculture, M30) were determined and expressed as a percentage of the control: $\mathrm{GI}=\left(\mathrm{M}_{30}-\mathrm{M} 0\right) / \mathrm{M} 0$. The total amount of $\mathrm{Fl}$ in the callus culture was quantified based on the colored Fl complexation with aluminum chloride followed by measurement of the optical density (a UV-1650 spectrophotometer, Shimadzu Corp., Japan). As a result of the studies, a dose-dependent effect of m$\mathrm{CBU}$ on cell growth was established due to their division $(0.1 \mu \mathrm{M})$ and stretching $(1-100 \mu \mathrm{M})$, which was accompanied by a 2.1-3.5-fold and 1.5-2.9-fold increase in the GIf and GId of callus culture, respectively $(\mathrm{p}<0.05)$. At a concentration of $0.1 \mu \mathrm{M}$, the number of small meristematic cells increased by $16 \%$ compared to the control. At the same time, the average volume of large cells decreased by $31 \%$ as compared to the control, which indicates inhibition of cell elongation processes. With the increase in m-CBU concentration, the frequency of cells of two groups increased, by 55 and $30 \%$ for medium-sized cells at 1 and $10 \mu \mathrm{M}$, respectively, and by 50 and $57 \%$ for large-sized cells at 1 and $100 \mu \mathrm{M}$, respectively. The volume of cells also increased compared to the control, by $61 \%$ at $10 \mu \mathrm{M}$ for large cells and by $18 \%$ at $100 \mu \mathrm{M}$ of small cells. m-CBU reduced the total amount of endogenous flavonoids by $80-95 \%$ ( $<<0.05)$ upon activation of growth processes in $S$. orgaadayi cells in vitro. The content of the total $\mathrm{Fl}$ decreased maximally at 0.01 and $0.1 \mu \mathrm{M}$ m-CBU and did not differ significantly from the control at $100 \mu \mathrm{M}$ m-CBU. The maximum 3.5-fold increase in GIf in the medium with $1 \mu \mathrm{M}$ m-CBU occurred simultaneously with an $83 \%$ decrease in the amount of Fl. $\mathrm{m}-\mathrm{CBU}$ can be used in plant biotechnology as a cell growth modulator in callus cultures to reduce the content of growth-inhibiting metabolites. To activate cell division, the most preferable dose is $0.1 \mu \mathrm{M}$ $\mathrm{m}-\mathrm{CBU}$, while to change the content of Fl, which doubles the biomass of the culture, $100 \mu \mathrm{M}$ $\mathrm{m}-\mathrm{CBU}$ should be used. flavonoids.

Keywords: Saussurea orgaadayi, cell culture, meta-chloro-benzhydryl urea, morphogenesis, 